\title{
Safeguarding Intangible Cultural Heritage in Brazil in accordance with the UNESCO Convention
}

\author{
Francisco Humberto Cunha Filho
}

For citation: Cunha Filho, Francisco Humberto. 2020. Safeguarding Intangible Cultural Heritage in Brazil in accordance with the UNESCO Convention. Pravovedenie 64 (1): 112-123.

https://doi.org/10.21638/spbu25.2020.109

\begin{abstract}
Brazil is a complex federation formed by 26 States, the Federal District and 5570 municipalities, all autonomous and sharing powers and duties in many legislative and administrative matters, such as culture and cultural heritage. On October $5^{\text {th }}, 1988$, the country adopted its first effectively democratic and pluralist Constitution, known as the "Citizen Constitution". It devotes special attention to the aforementioned topics based on the understanding that cultural heritage encompasses elements of a tangible and intangible nature that make reference to the identity, the action and the memory of the different groups that form Brazilian society, including textual mention of popular, indigenous and Afro-Brazilian cultures. In legal terms, however, it has been observed that since 1937 the country has had a national law for the protection of tangible cultural heritage, but only since 2000 has it issued a Decree on the safeguarding of intangible cultural heritage. In any case, this Decree precedes the UNESCO Convention on this subject, dated 2003 and incorporated into Brazilian law in 2006. At this time, the international regulation acquired a status of supranational to deal with matters pertaining to human rights. The content of the Convention did not result in any abrogation of the pre-existing rules in Brazil, however, it showed that the rules need to be complemented in two aspects. The first one, in a legal sense, to make explicit the humanitarian and environmental protection values that are indispensable in the policy of recognizing cultural manifestations and their elements. The second one, in a political sense given the characteristic of cooperative federalism, involves the necessity for the central government to stimulate the universalization of this policy in other entities of the Brazilian federation, which currently does not occur.
\end{abstract}

Keywords: Intangible Cultural Heritage, safeguard, UNESCO, Convention for Safeguarding of the Intangible Cultural Heritage, comparison, Brazilian law, constitutional law.

\section{Introduction}

The current Brazilian Constitution dates back to October $5^{\text {th }}, 1988$ and is considered the first truly democratic and pluralist one in the country, to the point that it's popularly called "Citizen Constitution", because, at least in the ideological field, interrupting a history of extreme injustices and social divisions, it has gained a long and almost utopian declaration of political, individual, collective, social, economic and cultural rights.

Concerning cultural rights, the Constitution adopted an enormous dimension of what should be understood as cultural heritage, in article 216, that "consists of the assets of a material and immaterial nature, taken individually or as a whole, which bear reference to the identity, action and memory of the various groups that form the Brazilian society, therein included: I — forms of expression; II — ways of creating, making and living; III scientific, artistic and technological creations; IV - works, objects, documents, buildings and other spaces intended for artistic and cultural expressions; V - urban complexes and

Francisco Humberto Cunha Filho - PhD, Professor, University of Fortaleza, 1321, Av. Washington Soares, Edson Queiroz, Fortaleza, 60811-905, Brazil; humbertocunha@unifor.br

() St. Petersburg State University, 2021 
sites of historical, natural, artistic, archaeological, paleontological, ecological and scientific value" 1 .

If the transcribed text is well observed, mainly the expression "immaterial", which means "intangible", and the first two items that exemplify cultural assets, there will be no difficulty in concluding that the Brazilian constitutional legislation precedes the Convention for the Safeguarding of Cultural Heritage in approximately 15 years.

In order to make the constitutional rule effective, in the year 2000 the Brazilian government issued what was known as the Decree for the Registration of Intangible Cultural Heritage and, as of that date, established a policy for the recognition and safeguarding of elements categorized as knowledge, celebrations, forms of expression, places, as well as an opening for those who can be submitted to other classifications.

With this history of precedence, this article aims to investigate what impacts the 2003 Convention caused on Brazilian law, focusing on two aspects: a juridical-normative, which seeks to know whether the international norms innovated Brazilian law, promoting abrogation or addition; and the other, of a political nature, which examines whether Brazil fulfills the state obligations defined for the countries that incorporated conventional commands into their order.

The method used in this research is the bibliographic investigation and consultation of official data systems, covering, in the exhibition of the content, a little of the political organization of Brazil, aiming to reveal how the task of safeguarding the Intangible Cultural Heritage ( $\mathrm{ICH}$, from now on) is shared in this federation. Thereafter, the federal legislation on general rules in this area is presented and applicable not only to the central government, but to almost 5600 entities of the Brazilian federation. Finally, the Convention for the Safeguarding of the Intangible Cultural Heritage of UNESCO ${ }^{2}$ (hereinafter, the Convention) is presented, specifically in the approaches, in order to have the basis that allows the conclusions of its impacts on Brazilian law.

\section{Overview of Brazil's political organization}

The first articulated sentence of the current Constitution of Brazil informs that the country is a democratic and federalist republic formed "by the indissoluble union of the states and municipalities and of the Federal District" (Art. 1), which form, in their unit, a person of public law, which is the Federal Union, all autonomous, under the constitutionally specified terms (Art. 18). In more didactic words, the Union represents, even at the international level, the unity of the nation; States are the largest internal political subdivisions and each comprise several Municipalities; there is also the Federal District, in which the capital of the country, Brasilia, is located, a small territorial area considering the Brazilian dimensions, and which in terms of political organization keeps a mix of characteristics of a Municipality and a State. These elements make the constitutionalist doctrine a preference for understanding that Brazil is a sui generis federation ${ }^{3}$ due to its complexity.

Focusing on States, according to Art. 25, they "are organized and governed by the Constitutions and laws they may adopt", observing the principles of the Federal Constitu-

1 In favor of the fluidity of the text, from now on it is understood that the literal citations (in quotes) of the Brazilian Constitution can be consulted in this reference: Brazil. Constitution of the Federative Republic of Brazil: Constitutional text of October 5, 1988, with the alterations introduced by Constitutional Amendments No. 1/92 through 72/2013 and by Revision Constitutional Amendments No. 1/94 through 6/94 / transl. and rev. by I. Vajda, P. Queiroz Carvalho Zimbres, V. T. de Souza. $6^{\text {th }}$ rev. ed. Brasilia: Undersecretariat of Technical Publications, 2013.

2 Text of the Convention for the Safeguarding of the Intangible Cultural Heritage // UNESCO. Available at: https://ich.unesco.org/en/convention (accessed: 01.06.2020).

3 Bonavides P., Andrade P. de. História Constitucional do Brasil. Brasília: OAB Editora, 2004. P. 453. 
tion, and, in addition, they have an apparently wide residual competence, because those that are not prohibited are reserved for them. However, one of the forms of prohibition is indirect and occurs when powers are given over a large amount of matters exclusively to other entities, which effectively manifests itself in the broad set of legislative and material powers attributed to the Union and, to a lesser extent, to the municipalities, which leaves Brazilian states in a situation so legally difficult that it provides doctrinal ironies such as realizing that they, in the face of the Federal Constitution, have two options: repeat it or violate it ${ }^{4}$.

The Brazilian Constitution does not list the political entities that are part of the country, because, according to Art. 18, § 3 , "The states may merge into each other, subdivide or dismember to be annexed to others or to form new states or federal territories, subject to the approval of the population directly concerned, by means of a plebiscite, and of the National Congress, by means of a supplementary law". During the entire term of the constitutional text, this never happened; therefore, since October 5, 1988, Brazil has maintained the 26 States that form its federation, each with a varied and variable number of Municipalities.

These States as well as the Federal District are linked to one of the five geographic regions of the country, namely: in the North Region are the States of Acre, Amapá, Amazonas, Pará, Rondônia, Roraima and Tocantins; in the Northeast Region are the States of Alagoas, Bahia, Ceará, Maranhão, Paraíba, Pernambuco, Piauí, Rio Grande do Norte and Sergipe; in the Midwest Region are the Federal District and the States of Goiás, Mato Grosso and Mato Grosso do Sul; in the Southeast Region, the States of Espírito Santo, Minas Gerais, Rio de Janeiro and São Paulo can be seen; and in the South Region, finally, the States of Paraná, Santa Catarina and Rio Grande do Sul.

At this point there is an important explanation to avoid a comparison error that may involve the word "Region", which has different meanings in Europe and in Brazil; in the old continent, it is usually an autonomous political entity under domestic law; in the South American country, according to Art. 43 of the Brazilian Constitution, it is only a "social and geoeconomic complex", in view of which the Union will be able to articulate its action, "seeking to attain its development and to reduce regional inequalities", devoid of, therefore, it has legal personality and its own powers and authorities.

Regarding the specific theme of culture, the Constitution follows the line of being minutely and verbose, to the point that it deserves a second vocation, that of "Cultural Constitution", because it disciplines this subject abundantly, dedicating several articles and a specific section to it ${ }^{5}$. For the time being, it should be noted that among the cultural themes, safeguarding collective memory is treated with great importance in the Brazilian Constitution (Art. 5 LXXIII), with a fundamental right status and, consequently, the historical and cultural heritage can be defended by each citizen, through a judicial measure called "popular action".

In terms of the distribution of competences in the matter, with regard to the creation of laws, Art. 24, in two of its items (VII and VIII), establishes that "The Union, the states and the Federal District have the power to legislate concurrently on: protection of the historic, cultural and artistic heritage, as well as of assets of touristic interest and landscapes of outstanding beauty; and liability for damages to the environment, to consumers, to assets and rights of artistic, aesthetic, historical, and touristic value, as well as to remarkable landscapes". It is important to remember that this competing legislative competence must be practiced as follows: the "Union shall be limited to the establishment of general rules";

4 Ferrari S. Constituição Estadual e Federação. Rio de Janeiro: Lúmen Júris, 2003.

5 Cunha Filho F. H. Teoria dos Direitos Culturais: fundamentos e finalidades. São Paulo: Edições SESC-SP, 2018. P. 115-135. 
States can exercise "supplementary competence", but if the Union fails to create general rules, those "exercise full legislative competence to provide for their peculiarities"; however, in this case, "the supervenience of a federal law over general rules suspends the effectiveness of a state law to the extent that the two are contrary" (Art. 24, § 1 to 4).

Concerning administrative matters, items III, IV and V of Article 23 of the Constitution specify that "The Union, the States, the Federal District and the Municipalities, in common, have the power: to protect the documents, works and other assets of historical, artistic or cultural value, the monuments, the remarkable landscapes and the archaeological sites; to prevent works of art and other assets of historical, artistic and cultural value from being taken out of the country, destroyed or from being deprived of their original characteristics; to provide the means of access to culture, education and science". In addition, the emphasis given by $\S 1$ of Art. 215 for the State to specifically protect "the expressions of popular, Indian and Afro-Brazilian cultures, as well as those of other groups participating in the national civilization process".

This framework of co-responsibility of public entities is extended to society by $\S 1$ of Art. 216, by prescribing that "The Government shall, with the cooperation of the community, promote and protect the Brazilian cultural heritage, by means of inventories, registers, vigilance, monument protection decrees, expropriation and other forms of precaution and preservation".

It is important to emphasize a second role for States: what they do has a paradigmatic value in relation to the Municipalities that compose it, since, according to Art. 30, IX, of the Constitution of Brazil, they are responsible to "promote the protection of the local historic and cultural heritage, with due regard for federal and state legislation and supervision".

\section{The Brazilian Register ${ }^{6}$ Decree}

Considering that the Convention for the Safeguarding of Intangible Cultural Heritage was adopted on October $17^{\text {th }}, 2003$, and signed on November $3^{\text {rd }}$, subsequently, Brazilian law, for this purpose, precedes it, because the legal discipline of registration for said assets is defined in Decree 3551 , of August $4^{\text {th }}, 2000^{7}$, which, by extension, created the National Program for Intangible Cultural Heritage ${ }^{8}$.

This anticipation has historical, economic and social justifications that, in order to be properly understood, it is necessary to remember, regarding the legal protection of Brazilian cultural heritage, that it began systematically in 1937, in the early days of the Vargas dictatorship ${ }^{9}$, in a delayed and prolonging period of the "heyday of statism" ${ }^{10}$, when Decree-Law no 25, dated November $30^{\text {th }}$ of that year, which created the "Tombamento"11, for many years the main normative instrument for the said task.

Historically and legally, the "Tombamento" is suitable for the protection of material cultural heritage, generally represented by churches, large buildings and monuments,

6 The main normative instrument for safeguarding intangible cultural heritage in Brazil is called "Registro", hereinafter referred to with this English word and its variations, according to phrasal adequacy.

7 The laws and decrees mentioned in this text, with their original wording and subsequent modifications, can be found at the following website: http://www4.planalto.gov.br/legislacao (accessed: 01.06.2020).

8 This program had a very successful period in supporting cultural elements recognized by the Federal Government, which led it to be inscribed on UNESCO's list of good practices in 2011.

9 Gomes Â. de C. Capanema - o ministro e seu ministério. Rio de Janeiro: Editora FGV, 2000.

10 Scovazzi T. La definizione di patrimonio culturale intangibile // Patrimonio culturale e creazione di valore / ed. by G. M. Golinelli. Padova: CEDAM, 2012. P. 156.

${ }_{11}$ A specific legal instrument for the protection of tangible cultural heritage existing only in the Brazilian law, which has some similarities with the "Classification" of the French law. 
typical of the owners of tangible property. It happens that the country is composed mainly of people of African and indigenous origin, who have almost no such tangible goods, but members of a cultural universe very rich in manifestations and symbols. In order to safeguard this immaterial cultural heritage, the Presidential Decree No. 3551 / 2000 was edited.

The signatory authority of this diploma, the President of the Republic, understood that the legitimacy to use this type of rule was based on art. 84, item IV, of the Federal Constitution ("The President of the Republic shall have the exclusive power to: sanction, promulgate and order the publication of laws, as well as to issue decrees and regulations for the true enforcement thereof"), and art. 14 of Law No. 9649, of May $27^{\text {th }}, 1998$. This Law provided for the organization of the Presidency of the Republic and its auxiliary bodies; with regard to the Ministry of Culture, it imposed the following responsibilities: "a) national culture policy; b) protection of historical and cultural heritage; c) to approve the delimitation of the lands of the remaining quilombo communities ${ }^{12}$, as well as to determine their demarcations, which will be ratified by decree".

The Register mentioned here is not to be confused with that of copyright, because unlike this one, it does not aim purely and simply for the accuracy of the authorship of a work in the world of culture, for the purpose of protecting moral or patrimonial rights, preventing unauthorized persons from using protected creations. The essence of the registration of intangible assets has an iconographic nature, in the sense of specifying as much as possible the description of ways of creating, doing, and living in order to make them public, offering parameters to those who want to reproduce them faithfully, respecting the other elements that were considered at the time of recognition ${ }^{13}$.

The aforementioned characterization takes place by inscribing the element in specific books, which are as follows:

- Knowledge: for the knowledge and ways of doing rooted in the daily lives of communities;

- Celebrations: for the rituals and popular festivities that mark the collective experience of work, religiosity, entertainment and other social life practices;

- Forms of Expression: for literary, musical, plastic, scenic and playful manifestations;

- Places: for markets, fairs, shrines, squares and other spaces where collective cultural practices are concentrated and reproduced. In addition to these, the Cultural Heritage Advisory Council may determine the opening of other books for the registration of cultural assets of an intangible nature that constitute Brazilian cultural heritage and that do not fit in the books expressly mentioned.

The description of the content of each book reveals the characteristics that the cultural asset must have in order to live up to the registration that formalizes its status as a member of the Brazilian cultural heritage, according to the category in which it fits. However, for all of them, the legislation requires two constant characteristics: historical continuity and national relevance to the memory, identity and formation of Brazilian society.

Thus, for an element to obtain registration, it must be demonstrated that it has the general characteristics of the members of the intangible cultural heritage and, as a rule (with the normative exception for "forms of expression"), the specific characteristics of its segment, as can be seen in the following table.

Operationally speaking, the Registry has its own administrative procedure, composed of the following phases: initiative; instruction; deliberation.

12 Community of slaves who fled slavery, which lasted until 1888, in Brazil.

13 Petrillo P. L. The Legal Protection of the Intangible Cultural Heritage: a Comparative Perspective. Cham: Springer, 2019. P. 249-250. 
Table. General and specific characteristics required by Brazilian law for ICH

\begin{tabular}{|c|c|c|}
\hline Asset & General characteristics & Specific characteristics \\
\hline $\begin{array}{l}\text { KNOWLEDGE } \\
\text { (Knowledge and ways of doing) }\end{array}$ & \multirow{5}{*}{$\begin{array}{l}\text { a) historical continuity } \\
\text { b) national relevance to the } \\
\text { memory, identity and forma- } \\
\text { tion of Brazilian society. }\end{array}$} & $\begin{array}{l}\text { a) rooting in the daily lives of } \\
\text { communities }\end{array}$ \\
\hline $\begin{array}{l}\text { CELEBRATIONS } \\
\text { (Rituals and parties) }\end{array}$ & & $\begin{array}{l}\text { a) the representation of the col- } \\
\text { lective experience of work, } \\
\text { religiosity, entertainment and } \\
\text { other social life practices. }\end{array}$ \\
\hline $\begin{array}{l}\text { FORMS OF EXPRESSION } \\
\text { (Literary, musical, plastic, scenic } \\
\text { and playful manifestations) }\end{array}$ & & \\
\hline $\begin{array}{l}\text { PLACES } \\
\text { (Markets, fairs, shrines, squares } \\
\text { and other spaces where collec- } \\
\text { tive cultural practices are con- } \\
\text { centrated and reproduced). }\end{array}$ & & $\begin{array}{l}\text { a) the concentration and repro- } \\
\text { duction of collective cultural } \\
\text { practices. }\end{array}$ \\
\hline $\begin{array}{l}\text { OTHERS } \\
\text { (That do not fit in the other } \\
\text { books) }\end{array}$ & & $\begin{array}{l}\text { a) failure to fit into other books } \\
\text { b) any other requirements estab- } \\
\text { lished when the new book was } \\
\text { created }\end{array}$ \\
\hline
\end{tabular}

Source: Prepared by the author.

The initiative, which consists of the power to provoke the registration process, was entrusted to the following persons and bodies: the Minister of State for Culture ${ }^{14}$; institutions linked to the Ministry of Culture; State, Municipal and Federal District Secretariats; civil societies or associations.

Proposals for registration must be addressed to the President of the National Historical and Artistic Heritage Institute — IPHAN (Instituto do Patrimônio Histórico e Artístico Nacional). Whoever submits the request must, in principle, prove the cultural value of the element, accompanying the request with the relevant technical documentation. The legislation specifies what should be understood by technical documentation, by establishing that there must be a detailed description of the asset to be registered, with the necessary proofs, in addition to mentioning all information that is culturally relevant to the process.

In order to facilitate and ensure the regularity of this task, the legislation foresees that the administrative registration processes will be supervised by IPHAN. However, if it is impossible for the proponent to instruct the petition, this will be done by other persons and bodies, such as those that make up the Ministry of Culture, the IPHAN units located in the States or entity (public or private), provided that they have specific knowledge about the matter.

Upon completion of the instruction, IPHAN will issue an opinion on the registration proposal; said opinion will be published in the Federal Official Gazette, so that, within 30 days, counted from its publication, eventual manifestations about the process are received. Once this period has elapsed, the existing random manifestations will be assessed and, with or without them, the process will be taken to the decision of the Cultural Heritage Advisory Council. With the registration, the following legal, political and social effects take

14 Currently, this ministry lost its status, becoming a secretariat linked to the Ministry of Tourism; despite this, the first designation is retained in this text, as it corresponds to the literalness of Decree No. $3551 / 2000$. 
place: registration in the corresponding book; designation with the title of "Cultural Heritage of Brazil"; documentation of the element registered by all admitted technical means; conservation of data with the material produced during the instruction of the process; wide dissemination and promotion of the element; receiving the benefits of the policies resulting from the National Intangible Heritage Program - PNPI (Programa Nacional do Patrimônio Imaterial), instituted by the Governing Decree, in which guidelines of its support and promotion policy "are designed to promote social inclusion and improve the living conditions of producers and holders of heritage intangible cultural heritage, and measures that expand the participation of groups"15.

There are those who add the occurrence of other effects, among which the opening of markets, being eloquent the case of "acarajé" (traditional food of the State of Bahia Brazil) that, in the face of having been recognized as intangible cultural heritage of Brazil, managed to break the monopoly of an exclusive contract between the International Football Federation (FIFA) and multinationals in the food and beverage industry, obtaining a decision that ensured that it was sold at the soccer stadium in the city of Salvador, which hosted matches for the 2014 World Cup ${ }^{16}$. On the other hand, the case is ideal to remember the fear of Freland ${ }^{17}$ regarding certain undesired effects such as those resulting from mass tourism that can follow heritage recognition.

It is important to note that the condition of "Cultural Heritage of Brazil", for the analyzed elements, is not for life. The legislation requires IPHAN to reassess registered cultural assets, at least every ten years, and forward it to the Cultural Heritage Advisory Council to decide on the revalidation of the title. In case of denial, it will still be registered as a memory and cultural reference in the period in which it was valid.

It should be noted that this Brazilian legislation is predominantly descriptive and, therefore, silent on the set of values that permeate and surround the cultural elements that can be recognized, that is, it does not contain directly indicative of respect for human rights, tolerance, diversity, to the environment etc. This is necessary, for example, when even the Supreme Court, having considered the "vaquejada" (game with cattle) unconstitutional, because it is cruel to animals, lawmakers declared it cultural heritage in Brazil, creating an amendment in the Constitution for this purpose.

As a result of this legislation, until May 2020, the following assets have already been registered as intangible cultural heritage in Brazil:

- Celebrations: Festa ${ }^{18}$ de Sant'Ana de Caicó/RN; Círio de Nossa Senhora de Nazaré/PA; Complexo Cultural do Bumba-meu-boi do Maranhão; Festa do Divino Espírito Santo de Pirenópolis/GO; Ritual Yaokwa do povo indígena Enawene Nawe; e Festa do Divino de Paraty); Procissão do Senhor dos Passos de Santa Catarina;

- Forms of Expression: Arte Kusiwa - pintura corporal e arte gráfica Wajâpi" Toque dos $\operatorname{Sinos}^{20}$ em Minas Gerais tendo como referência São João del Rey e as Cidades de Ouro Preto, Mariana Cartas Altas, Congonhas do Campo, Diamantina, Sabará, Serro e Tiradentes; Frevo; Jongo do Sudeste; Matrizes do Samba do Rio

15 Programa Nacional do Patrimônio Imaterial (PNPI) // Instituto do Patrimônio Histórico e Artístico Nacional. IPHAN. Available at: http://portal.iphan.gov.br/pagina/detalhes/761 (accessed: 06.05.2020).

16 Guanais E. Queroz H. F. O. Revista do IPAC. Instituto do Patrimônio Artístico e Cultural da Bahia. Vol. 1. Salvador: SECULT-BA/IPHAN, 2016.

17 Freland F. - X. Capturing the intangible: perpectives on the living heritage. Paris: UNESCO, 2009. P. 23.

\footnotetext{
18 "Festa" is a Portuguese word that refers to "popular festivities".

19 Body painting and graphic arts.

20 Ringing of the church bells in the mentioned cities.
} 
de Janeiro: partido alto, samba de terreiro e samba-enredo; Samba de Roda do Recôncavo Baiano; Tambor de Crioula do Maranhão; Roda de Capoeira; Marabaixo; Literatura de Cordel;

- Places: Cachoeira ${ }^{21}$ do lauaretê - lugar sagrado dos povos indígenas dos rios Uapés e Papuri; Feira ${ }^{22}$ de Caruaru/PE; and

- Knowledge: Sistema Agrícola Tradicional ${ }^{23}$ do Rio Negro; Modo de fazer violade-cocho; ofício dos mestres de capoeira; ofício de sineiros; modo artesanal de fazer queijo de Minas nas regiões de Serro e das serras da Canastra e do Salitre/ Alto Parnaíba; ofício das baianas de acarajé; ofício das paneleiras de Goiabeiras/ES; modo de fazer renda irlandesa tendo como referência este ofício em Divina Postora/SE; e saberes e práticas associados ao modo de fazer Bonecas Karajás ${ }^{24}$.

The first surveys on the subject showed that federal legislation, in terms of general rules, had repercussions in approximately half of the States of Brazil ${ }^{25}$, and in an unidentified number of Municipalities. This assertion could be called into question by observing Goal 5, of the National Culture Plan, according to which, by 2020, the "National Cultural Heritage System should be implemented, with $100 \%$ of the States and $60 \%$ of the Municipalities with legislation and heritage policies approved", that is, "in all States and in 3339 cities in Brazil". In determining the fulfillment of this goal, until 2018, the Federal Secretariat of Culture offers ambiguous information, saying that 26 States and $1768 \mathrm{Mu}-$ nicipalities have "cultural heritage legislation approved", but does not specify whether this legislation includes the $\mathrm{ICH}$; in addition, the aforementioned body highlights that the measurement of the goal "does not present data from States or Municipalities that have legislation and heritage policy, but only if there is heritage legislation" 26.

With the internalization of the Convention to the Brazilian legal system, the possibility of changes in federal legislation arose, in order to produce a cascade effect for the other entities of the federation (States and Municipalities), since this type of international document has, in the country, in the face of a decision by the Supreme Court, a supra-legal force, hierarchically positioned between the Constitution and the laws. This hypothesis, therefore, needs to be investigated, and it will be in the next topic.

\section{State responsibilities}

The safeguarding of intangible cultural heritage must correspond to measures aimed to ensure its viability, such as identification, documentation, research, preservation, protection, promotion, enhancement, diffusion - essentially through formal education and non-formal - and revitalization of this heritage in its various aspects. Such measures are the direct responsibility of the States, but they must be carried out with the participation of the relevant communities, groups, and non-governmental organizations and, when appropriate, the individuals who create, maintain and transmit this heritage and who are actively associated with its management. For these, and especially for communities

21 Waterfall.

22 Popular Market.

23 Traditional agricultural system of Rio Negro (Brazilian Amazon).

24 These lists can be viewed updated on the website: www.iphan.gov.br (accessed: 25.04.2020).

25 Castro M. L. V., Fonseca M. C. L. Patrimônio Imaterial no Brasil. Brasília: UNESCO, Educarte, 2008.

26 Secretaria Especial da Cultura. Plano Nacional de Cultura. Available at: http://pnc.cultura.gov.br/ category/metas/5 (accessed: 25.04.2020). 
and NGOs, Kono ${ }^{27}$ and Zingari ${ }^{28}$ advocate more participation, as communities are truly responsible for intangible cultural heritage and NGOs for the propulsion of activities and demands in face of the constituted authorities. Blake ${ }^{29}$ adds, regarding the Convention, that communities are still in the "infantile" stage, reinforcing the need to increase their participation, assuming that this way they will acquire maturity to exercise their role in safeguarding activities.

In addition, international cooperation and assistance for the exchange of information and experiences, the development of common initiatives, and the creation of mechanisms to support States that, based on their national norms, legislated or resulting from customary practices, can be activated, recognizing that the safeguarding of intangible cultural heritage is a matter of general interest to humanity and, as a result, undertake to cooperate on a bilateral, sub-regional, regional and international level, in the aforementioned area.

Being more specific about what should be done, the Convention, within a range that contemplates many other possibilities of protection at the international level ${ }^{30}$, specifies some instruments, activities, and behaviors, aiming at multiple purposes, which range from knowledge to promotion, but whenever possible with the participation of interested parties and respect for their practices.

Thus, to ensure identification, it is necessary to create inventories, regularly updated; these instruments go beyond mere census. There is an understanding that the fact that an intangible cultural asset appears on the list of inventories as having a different cultural value, this represents more than knowledge and is configured as recognition and increases the feeling of importance for those directly interested, for the society in which it operates and for the others with which it relates.

In order to ensure the safeguarding, development and enhancement of the intangible cultural heritage, the States, which may eventually receive international assistance, through the Convention have also committed themselves to: adopting a planned and integrated policy as a whole for public policies; create or designate specific organism(s) to deal with the matter; foster scientific, technical and artistic studies, as well as research methodologies on the subject; adopt the appropriate legal, technical, administrative and financial measures to, in addition to instrumentalizing the aforementioned actions, stimulate tradition and guarantee access to the heritage in question, including the natural spaces and places of memory essential to it, respected, as much as possible, the customs that are inherent to them. Such actions must present periodic reports, to be analyzed by the body designated in the Pact under study, namely, the Management Committee and, based on its report, to the General Assembly.

However, the participants of the Convention reveal that the insufficiency of the actions of the law, the economy and technologies for such an important and delicate purpose, by advocating values such as education, awareness and capacity building (training), emphasizing the need to specific programs, including by non-formal means, aimed at young people, communities and groups involved.

27 Kono T. Convention for safeguarding of intangible cultural heritage - unresolved issues and unanswered questions // Intangible Cultural Heritage and Intellectual Property / ed. by Toshiyuki Kono. Antwerp; Oxford; Portland: Intersentia, 2009. P. 30.

28 Zingari V. L. Ascoltare i territori e le comunità - le voci delle associazioni non governative (ONG) // II patrimonio culturale immateriale - Venezia e il Veneto come patrimonio europeo / ed. by M. L. P. Forlati. Venezia: Edizioni Ca'Foscari, 2014. P. 71.

29 Blake J. International cultural heritage law. Oxford: Oxford University Press, 2015. P. 185.

30 Mucci F. La diversità del patrimonio e delle espressioni culturali nell'ordinamento internazionale da "ratio" implicita a oggetto diretto di protezione. Napoli: Editoriale Scientifica, 2012. P. 167. 
Furthermore, they understand that the feeling of co-responsibility of the entire social group must be developed, by emphasizing the obligation to keep the public informed of the threats that affect the heritage and, in a preventive or restorative reaction to them, of the activities carried out to protect it.

For the present study, it should be noted that the Convention assigns its Article 35 specifically to discipline as it should be applied in "federal or non-unitary constitutional systems", of particular interest for the research now carried out, given the characteristics of the political organization of Brazil (Federation). For these States, it has been established that the provisions of the Convention within the competence of the central government, the obligations of the federal power will be identical to those of States that are not federal states; and with respect to the provisions of which application is attributed to each of the constituent States, countries, provinces or cantons, which, as a result of the constitutional regime of the federation, are not obliged to take legislative measures, the federal government will communicate them, with a favorable opinion, to the competent authorities of sub-national entities, with their recommendation for approving the mentioned policies.

In more accessible words, in complex (non-unitary) states, the Convention establishes two types of obligations for the central government, depending on whether, as in the matter of protecting intangible cultural heritage, it is the competence of the central entity or fractional entities. When the central government is in charge, it responds to the international community as if it were a unitary state; in case of sub-national entities in charge, the Federal Union will internally encourage compliance with the Pact. The Convention does not make it clear what the allocation is in the case of shared powers (legislative and administrative), it should be said, in this case, that the central power has both functions.

\section{Conclusions}

From the framework presented, we start to contrast how Brazilian law, practices and cultural policies with the precepts of the Convention, in order to detect their similarities and divergences and to observe the fulfillment of the two objective outlines for this research.

In legal-normative terms, it can be said that the Brazilian legislation regarding the $\mathrm{ICH}$ has not been revoked; in fact, it was fully received; however, it should have been expanded to include the axiological dimension of the Convention, according to which cultural recognition cannot include elements and manifestations incompatible with human dignity, sustainable development, peace and respect between human beings and between them and with other beings and the environment.

As for the political impact, despite Brazil's recognition of good practice in terms of safeguarding the $\mathrm{ICH}$, in recent years these policies have lost priority, with budget cuts, political discrediting of cultural bodies in general and of heritage specifically.

Furthermore, the safeguarding role that the central government should have in the face of other entities of the federation, despite being provided for in the Law establishing the National Culture Plan, is a policy that is at very unsatisfactory levels.

In summary, the entire cultural and political environment is favorable to full compatibility between the UNESCO Convention and Brazilian law, but the valuation and integration aspects of public policies within the scope of the Brazilian federation, which the international document aims to disseminate, are still underutilized in Brazil. 


\section{References}

Blake, Janet. 2015. International cultural heritage law. Oxford, Oxford University Press.

Bonavides, Paulo, Andrade, Paes de. 2004. História Constitucional do Brasil. Brasília, OAB Editora.

Castro, Maria Laura Viveiro, Fonseca, Maria Cecília Londres. 2008. Patrimônio Imaterial no Brasil. Brasília, UNESCO, Educarte.

Cunha Filho, Francisco Humberto. 2018. Teoria dos Direitos Culturais: fundamentos e finalidades. São Paulo, Edições SESC-SP.

Ferrari, Sérgio. 2003. Constituição Estadual e Federação. Rio de Janeiro, Lúmen Júris.

Freland, François-Xavier. 2009. Capturing the intangible: perpectives on the living heritage. Paris, UNESCO.

Gomes, Ângela de Castro. 2000. Capanema - o ministro e seu ministério. Rio de Janeiro, Editora FGV.

Guanais E. Queroz, Hermano Fabrício Oliveira. 2016. Revista do IPAC/Instituto do Patrimônio Artístico e Cultural da Bahia, vol. 1. Salvador, SECULT-BA/IPHAN.

Kono, Toshiyuki. 2009. Convention for safeguarding of intangible cultural heritage - unresolved issues and unanswered questions. Intangible Cultural Heritage and Intellectual Property, ed. by Toshiyuki Kono: 3-42. Antwerp, Oxford, Portland, Intersentia.

Mucci, Federica. 2012. La diversità del patrimonio e delle espressioni culturali nell'ordinamento internazionale - da "ratio" implicita a oggetto diretto di protezione. Napoli, Editoriale Scientifica.

Petrillo, Pier Luigi. 2019. The Legal Protection of the Intangible Cultural Heritage: a Comparative Perspective. Cham, Springer.

Scovazzi, Tullio. 2012. La definizione di patrimonio culturale intangibile. Patrimonio culturale e creazone di valore, ed. by Gaetano M. Golinelli, 151-184. Padova, CEDAM.

Vajda, Istvan, Queiroz Carvalho Zimbres, Patrícia de, Tavares de Souza, Vanira (transl. and rev.) 2013. Constitution of the Federative Republic of Brazil: Constitutional text of October 5, 1988, with the alterations introduced by Constitutional Amendments No. 1/92 through 72/2013 and by Revision Constitutional Amendments No. 1/94 through 6/94. $6^{\text {th }}$ rev. ed. Brasilia, The Federal Senate, Undersecretariat of Technical Publications.

Zingari, Valentina Lapiccirella. 2014. Ascoltare i territori e le comunità - le voci delle associazioni non governative (ONG). II patrimonio culturale immateriale - Venezia e il Veneto come patrimonio europeo, ed. by Maria Laura Picchio Forlati: 71-92. Venezia, Edizioni Ca’Foscari.

Received: June 18, 2020

Accepted: December 23, 2020

\section{Охрана нематериального культурного наследия в Бразилии в соответствии с Конвенцией ЮНЕСКО}

Ф. У. Куна Фило

Для цитирования: Cunha Filho, Francisco Humberto. Safeguarding Intangible Cultural Heritage in Brazil in accordance with the UNESCO Convention // Правоведение. 2020. T. 64, № 1. С. 112-123. https://doi.org/10.21638/spbu25.2020.109

Бразилия представляет собой сложную федерацию, образованную 26 штатами, федеральным округом и 5570 муниципалитетами, все они автономны и разделяют полномочия и обязанности во многих законодательных и административных вопросах, таких как культура и культурное наследие. 5 октября 1988 г. страна приняла свою первую действительно демократическую и плюралистическую Конституцию, называемую «гражданской конституцией», так как она уделяет особое внимание вышеупомянутым вопросам и основывается на том, что культурное наследие включает в себя материальные и нематериальные элементы, отсылающие к идентичности, образу жизни и памяти различных групп, образующих бразильское общество; в тексте Конституции упоминаются народная, коренная и афробразильская культуры. С 1937 г. в стране действует национальный закон об охране материального культурного наследия, однако Декрет об охране нема- 
териального наследия действует только с 2000 г. Этот Декрет предшествует Конвенции ЮНЕСКО 2003 г. по данному вопросу, инкорпорированной в бразильское законодательство в 2006 г., когда этот международный регламент приобрел статус наднационального для рассмотрения вопросов, касающихся прав человека. Содержание Конвенции не привело к отмене ранее существовавших в Бразилии правил, однако показало, что эти правила нуждаются в дополнении по двух направлениям - юридическому и политическому. Во-первых, нужно сформулировать гуманитарные и природоохранные ценности, которые необходимы в политике признания культурных проявлений и их элементов. Во-вторых, нужно учитывать характерную для кооперативного федерализма черту: центральное правительство должно стимулировать универсализацию этой политики в других субъектах бразильской федерации, чего в настоящее время не происходит.

Ключевые слова: нематериальное культурное наследие, охрана, ЮНЕСКО, Международная конвенция об охране нематериального культурного наследия, сравнение, бразильское право, конституционное право.

Статья поступила в редакцию: 18 июня 2020 г. Рекомендована в печать: 23 декабря 2020 г.

Куна Фило Франсиско Умберто - PhD, профессор, Университет Форталезы, Бразилия, 60811905, Форталеза, Эдсон Кейрос, пр. Вашингтон Суарес, 1321; humbertocunha@unifor.br 